\title{
PATTERN RECOGNITION: EFFECTIVENESS OF TEACHING BOYS AGED 15 A CARTWHEEL
}

\author{
Dmytro Ivanov $^{1 \mathrm{ABCD}}$, Olha Ivashchenko ${ }^{1 \mathrm{ABCD}}$, Pavol Bartik ${ }^{2 A C D}$ \\ ${ }^{1}$ H. S. Skovoroda Kharkiv National Pedagogical University \\ ${ }^{2}$ Matej Bel University \\ Authors' Contribution: A - Study design; B - Data collection; C - Statistical analysis; D - Manuscript Preparation; E - Funds Collection
}

DOI: $10.17309 / \mathrm{jltm} .2021 .3 .01$

\begin{abstract}
The purpose of the study was to determine the impact of the number of repetitions on the effectiveness of teaching boys aged 15 a cartwheel.

Materials and methods. The study participants were 20 boys aged 15 . The children and their parents were fully informed about all the features of the study and gave their consent to participate in the experiment. To solve the tasks set, the following research methods were used: study and analysis of scientific and methodological literature; pedagogical observation, timing of training tasks; pedagogical experiment, methods of mathematical statistics, discriminant analysis.

Results. The assumption was made about a significant influence of the modes of alternating exercise repetitions and the rest interval on the effectiveness of motor skills development in boys aged 15. The study found that 6 sets 1 time each with a rest interval of $60 \mathrm{~s}$ are more effective than 6 sets 2 times each with a rest interval of $60 \mathrm{~s}$ when teaching the ability to assess movement performance by time $(\mathrm{p}<0.001)$. And with the first exercise mode, fewer repetitions are needed to master the entire cartwheel. This is due to the fact that differentiation of time characteristics requires immediate information about the movement performance after each repetition.

Conclusions. Based on the analysis of group centroids, it was found that 6 repetitions of the exercise (6 sets 1 time each with a rest interval of $60 \mathrm{~s}$ ) significantly influence the cartwheel skill development in boys aged 15 during physical education classes. The results of group classification show that $95.0 \%$ of the original grouped observations were classified correctly.

Keywords: discriminant analysis, boys, acrobatic exercises, exercise mode.
\end{abstract}

\section{Introduction}

Physical education is an important factor in the development of schoolchildren's personal qualities and a healthy lifestyle (Krutsevich, et al. 2021; Cisterna, et al., 2019; Elezi, et al., 2021). Motor skills development in schoolchildren is the main task of the modern school (Ivashchenko, 2020; Kapkan et al., 2019a,b). Studies focus on optimizing the teaching of basic movements (Herrmann et al., 2019; Morley et al., 2019; Samsudin et al., 2021).

The modes of alternating exercises and rest intervals are considered as a factor that influences the effectiveness of teaching (Burstein et al., 2021; Ivashchenko et al., 2017; Ivashchenko et al., 2015). A dosed load is also used when developing movement control skills (Ivashchenko et al., 2019) and motor abilities (Ivashchenko et al., 2021; Khudolii et al., 2020; Marchenko et al., 2021).

(C) Ivanov, D., Ivashchenko, O., \& Bartik, P., 2021.
One of the methods of studying the patterns of motor skills development is modeling (Khudolii et al., 2020; Ivashchenko, 2020; Ivashchenko et al., 2021). Positive results were obtained during discriminant analysis of the impact of strength exercises on the level of motor fitness (Samanta et al., 2021) and motor skills development in schoolchildren (Iermakov, Ivashchenko et al., 2021; Iermakov et al., 2021). Therefore, it is relevant to study the impact of different exercise modes on the effectiveness of teaching schoolchildren aged 15 acrobatic exercises.

The purpose of the study was to determine the impact of the number of repetitions on the effectiveness of teaching boys aged 15 a cartwheel.

\section{Material and methods}

\section{Study participants}

The study participants were 20 boys aged 15 . The children and their parents were fully informed about all the fea- 
tures of the study and gave their consent to participate in the experiment.

\section{Organization of the study}

To solve the tasks set, the following research methods were used: study and analysis of scientific and methodological literature; pedagogical observation, timing of training tasks; pedagogical experiment, methods of mathematical statistics, methods of mathematical experiment planning, discriminant analysis.

The pedagogical experiment was conducted at the lyceum No. 107, Kharkiv, in the 2020-2021 academic years.

The pedagogical experiment examined the influence of 6 and 12 repetitions with a 60 -second rest interval during a physical education class on the number of repetitions of training tasks to the $100 \%$ level of proficiency. In the first group, the boys repeated the tasks 6 sets 1 time each with a rest interval of $60 \mathrm{~s}$, in the second group - 6 sets 2 times each with a rest interval of $60 \mathrm{~s}$.

During teaching, the method of algorithmic instructions was used (Shlemin, 1973). The program of teaching the cartwheel was developed based on the data of Shlemin (1973), Khudolii (2008) and included the following training tasks:

The first series of training tasks - exercises to develop motor abilities

1. From normal standing position, lean forward, touch the floor with the hands and, moving the hands forward on the floor, adopt a push-up position, return to starting position in the same way 3-4s)

2. Perform push-ups as quickly as possible (5 times in

The second series of training tasks - exercises to master starting and ending positions

1. From standing position with raised arms, step forward and perform a switch leg handstand with assistance

2. Handstand with legs apart with assistance

The third series of training tasks - actions without which it is impossible to perform the target exercise

1. Standing on hands with legs apart with assistance, shift the body weight from one hand to the other

The fourth series of training tasks - teaching the ability to assess movements in space, by time and muscular effort

1. Arriving to handstand quickly with assistance

2. Arriving to handstand slowly with assistance

The fifth series of training tasks - preliminary exercises

1. Arriving to handstand quickly with the wall support
2. Handstand with legs apart with 90 -degree rotation with assistance

The sixth series of training tasks - the entire exercise

1. Cartwheel with assistance.

2. Cartwheel without assistance

The next exercise started on condition of correct performance of the previous exercise on three consecutive attempts. The number of repetitions required for correct performance on three consecutive attempts was recorded. The level of proficiency in the exercises was determined by the alternative method: "performed" or "failed". A technically correct performance of the exercise gave the students " 1 " point; a failure to perform the exercise gave them "0" entered in the protocol.

\section{Statistical analysis}

The study materials were processed using the IBM SPSS 20 statistical analysis program. Discriminant analysis was conducted. For each canonical discriminant function, the study calculated the following: eigenvalue, variance percentage, canonical correlation, Wilks' lambda, Chi-square. For each step: prior probabilities, Fisher's function coefficients, unstandardized function coefficients, Wilks' lambda for each canonical function.

The study protocol was approved by the Ethical Committee of the University. In addition, the children and their parents or legal guardians were fully informed about all the features of the study, and a signed informed consent document was obtained from all the parents.

\section{Results}

Table 1 provides the statistics for the groups. The analysis of mean values shows that statistically significant differences in the number of repetitions are observed in the first and fourth series of training tasks $(p<0.05)$. The 15 -year-old boys who use the first mode need fewer repetitions to master the movements of the first and fourth series of tasks than the 15 -year-old boys who use the second mode of training. The 15-year-old boys who use the second mode need fewer repetitions to master the movements of the sixth series of tasks than the 15-year-old boys who use the first mode of training $(\mathrm{p}<0.1)$.

To determine the impact of different modes of exercises on the level of proficiency, discriminant analysis was conducted (see Tables 2-9). The results of the Box's M test con-

Table 1. Group Statistics. Boys Aged 15

\begin{tabular}{|c|c|c|c|c|c|c|c|c|c|c|}
\hline \multirow{2}{*}{$\begin{array}{l}\text { Series of } \\
\text { tasks }\end{array}$} & \multicolumn{2}{|c|}{$\begin{array}{c}6 \text { repetitions, rest interval } \\
\text { of } 60 \mathrm{~s} \\
\end{array}$} & \multicolumn{2}{|c|}{$\begin{array}{l}12 \text { repetitions, rest interval } \\
\text { of } 60 \mathrm{~s} \\
\end{array}$} & \multirow{2}{*}{$\Delta \mathbf{x}$} & \multirow{2}{*}{$\begin{array}{l}\text { Wilks' } \\
\text { Lambda }\end{array}$} & \multirow{2}{*}{$\mathbf{F}$} & \multirow{2}{*}{ df1 } & \multirow{2}{*}{ df2 } & \multirow{2}{*}{ Sig } \\
\hline & Mean & Std. Deviation & Mean & Std. Deviation & & & & & & \\
\hline 1 series & 6.3 & 1.77 & 10.0 & 1.88 & -3.7 & .468 & 20.501 & 1 & 18 & .000 \\
\hline 2 series & 4.2 & .79 & 4.7 & .48 & -0.5 & .860 & 2.922 & 1 & 18 & .105 \\
\hline 3 series & 6.6 & 2.79 & 6.2 & 2.04 & 0.4 & .993 & .133 & 1 & 18 & .719 \\
\hline 4 series & 4.8 & 1.61 & 13.3 & 2.75 & -8.5 & .202 & 70.911 & 1 & 18 & .000 \\
\hline 5 series & 5.0 & 2.21 & 6.6 & 2.87 & -1.6 & .902 & 1.946 & 1 & 18 & .180 \\
\hline 6 series & 9.7 & 1.34 & 8.0 & 2.45 & 1.7 & .829 & 3.710 & 1 & 18 & .070 \\
\hline
\end{tabular}


firm the assumption about the homogeneity of variances and covariances used in the discriminant analysis and indicate the possibility of its use (Table 2).

Table 2. Box's M Test For Testing Equal Population Covariance Matrices (DA)

\begin{tabular}{rlr}
\hline & Box's $\mathbf{M}$ & $\mathbf{4 9 . 0 8 8}$ \\
\hline & Approx. & 1.471 \\
F & df1 & 21 \\
& df2 & 1191.671 \\
& Sig. & .078 \\
\hline
\end{tabular}

The first canonical function explains $100 \%$ of the results variation, which indicates its high informativity $(r=0.915)$ (see Table 3 ). The materials of the canonical function analysis show its statistical significance $\left(\lambda_{1}=0.163 ; \mathrm{p}_{1}=0.001\right)$. The first function has a high discriminative ability and value in interpretation of the general population (Tables 3, 4).

Table 3. Eigenvalues for Developing Discriminant Model (Canonical Correlation). Boys Aged 15

\begin{tabular}{ccccc}
\hline Function & Eigenvalue & $\begin{array}{c}\text { \% of } \\
\text { Variance }\end{array}$ & $\begin{array}{c}\text { Cumulative } \\
\%\end{array}$ & $\begin{array}{c}\text { Canonical } \\
\text { Correlation }\end{array}$ \\
\hline 1 & 5.120 & 100.0 & 100.0 & .915 \\
\hline
\end{tabular}

Table 4. Outcomes of Calculated Wilks' Lambda of Discriminant Function. Boys Aged 15

\begin{tabular}{ccccc}
\hline Test of Function(s) & Wilks' Lambda & Chi-square & df & Sig. \\
\hline 1 & .163 & 27.173 & 6 & .000 \\
\hline
\end{tabular}

The standardized canonical discriminant function coefficients make it possible to determine the ratio of the contribution of variables to the function result. The results of the first and fourth series of training tasks make the largest contribution to the first canonical function. The above indicates that the exercises of the first and fourth series of training tasks are the most sensitive to the number of repetitions in boys aged 15 (Table 5).

Table 5. Standardized Canonical Discriminant Function Coefficients. Boys Aged 15

\begin{tabular}{cc}
\hline Series of tasks & Function \\
\cline { 2 - 2 } & $\mathbf{1}$ \\
\hline 1 & .263 \\
3 & .081 \\
4 & -.356 \\
5 & .957 \\
6 & -.297 \\
\hline
\end{tabular}

The structure canonical discriminant function coefficients are the coefficients of correlation between the variables and the function. Thus, the function is most closely connected with the number of repetitions of exercises of the first and fourth series of training tasks (Table 6).

The coordinates of centroids for two groups make it possible to interpret the canonical function in relation to the role in classification. At the positive pole is a centroid for the
Table 6. Structure Matrix. Boys Aged 15

\begin{tabular}{cc}
\hline Series of tasks & Function \\
\cline { 2 - 2 } & \multicolumn{1}{c}{$\mathbf{1}$} \\
\hline 4 & .877 \\
1 & .472 \\
6 & -.201 \\
2 & .178 \\
5 & .145 \\
3 & -.038 \\
\hline
\end{tabular}

Table 7. Canonical Discriminant Function Coefficients (Unstandardized coefficients)

\begin{tabular}{llc}
\hline \multirow{2}{*}{ Series of tasks } & Function \\
\cline { 2 - 3 } & 1 & $\mathbf{1}$ \\
\hline & 2 & .144 \\
& 3 & .124 \\
& 4 & -.145 \\
& 5 & .424 \\
& 6 & -.116 \\
(Constant) & & -.130 \\
\hline
\end{tabular}

Table 8. Functions at Group Centroids. Boys Aged 15

\begin{tabular}{ll}
\hline \multicolumn{1}{c}{ Exercise Mode } & \multicolumn{1}{c}{ Function } \\
\cline { 2 - 3 } & \multicolumn{1}{c}{$\mathbf{1}$} \\
\hline $1-6$ repetitions, rest interval of $60 \mathrm{~s}$ & -2.147 \\
$2-12$ repetitions, rest interval of $60 \mathrm{~s}$ & 2.147 \\
\hline
\end{tabular}

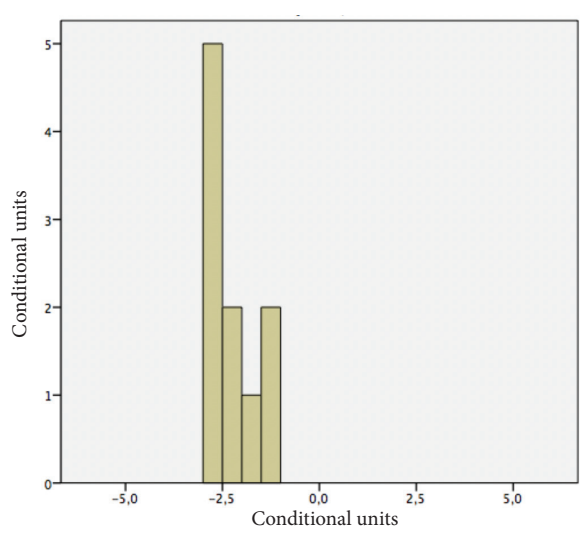

Fig. 1. Graphic representation of classification results: 6 repetitions, rest interval of $60 \mathrm{~s}$

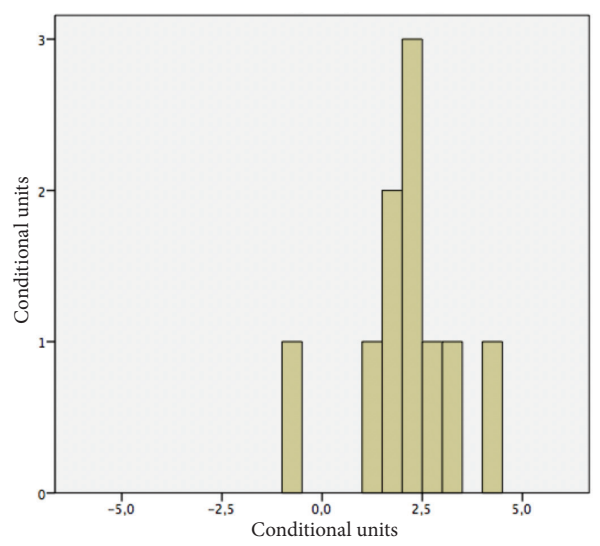

Fig. 2. Graphic representation of classification results: 12 repetitions, rest interval of $60 \mathrm{~s}$ 
Table 9. Classification Results ${ }^{\mathrm{a}, \mathrm{c}}$

\begin{tabular}{|c|c|c|c|c|c|}
\hline & & \multirow{2}{*}{ Exercise mode } & \multicolumn{2}{|c|}{$\begin{array}{l}\text { Predicted Group } \\
\text { Membership }\end{array}$} & \multirow{2}{*}{ Total } \\
\hline & & & & & \\
\hline \multirow{4}{*}{ Original } & \multirow{2}{*}{ Count } & $1-6$ repetitions, rest interval of $60 \mathrm{~s}$ & 10 & 0 & 10 \\
\hline & & $2-12$ repetitions, rest interval of $60 \mathrm{~s}$ & 1 & 9 & 10 \\
\hline & \multirow{2}{*}{$\%$} & $1-6$ repetitions, rest interval of $60 \mathrm{~s}$ & 100.0 & .0 & 100.0 \\
\hline & & $2-12$ repetitions, rest interval of $60 \mathrm{~s}$ & 10.0 & 90.0 & 100.0 \\
\hline \multirow{4}{*}{ Cross-validated ${ }^{\mathrm{b}}$} & \multirow{2}{*}{ Count } & $1-6$ repetitions, rest interval of $60 \mathrm{~s}$ & 9 & 1 & 10 \\
\hline & & $2-12$ repetitions, rest interval of $60 \mathrm{~s}$ & 1 & 9 & 10 \\
\hline & \multirow{2}{*}{$\%$} & $1-6$ repetitions, rest interval of $60 \mathrm{~s}$ & 90.0 & 10.0 & 100.0 \\
\hline & & $2-12$ repetitions, rest interval of $60 \mathrm{~s}$ & 10.0 & 90.0 & 100.0 \\
\hline
\end{tabular}

a. $95.0 \%$ of original grouped cases correctly classified. b. Cross validation is done only for those cases in the analysis. In cross validation, each case is classified by the functions derived from all cases other than that case. c. $90.0 \%$ of cross-validated grouped cases correctly classified.

exercise mode of 12 repetitions, at the negative - a centroid for the exercise mode of 6 repetitions (see Table 10, Fig. 1,2). This indicates a significant difference in the impact of exercise repetition modes on the number of repetitions required for motor skills development in boys aged 15 during physical education classes. The results of group classification show that $95.0 \%$ of the original grouped observations were classified correctly.

\section{Discussion}

The assumption was made about a significant influence of the modes of alternating exercise repetitions and the rest interval on the effectiveness of motor skills development in boys aged 15 . The study found that 6 sets 1 time each with a rest interval of $60 \mathrm{~s}$ are more effective than 6 sets 2 times each with a rest interval of $60 \mathrm{~s}$ when teaching the ability to assess movement performance by time $(p<0.001)$. And with the first exercise mode, fewer repetitions are needed to master the entire cartwheel. This is due to the fact that differentiation of time characteristics requires immediate information about the movement performance after each repetition. The results presented confirm the data of Iermakov et al. (2021), Ivashchenko et al. (2015), Kapkan et al. (2019b) about the influence of exercise modes on the effectiveness of motor skills development in schoolchildren.

The obtained data supplement the results of the studies on motor skills development in schoolchildren (Iermakov, Ivashchenko et al., 2021; Iermakov et al., 2021); on coordination abilities development (Warlop et al., 2020; Strotmeyer et al., 2020); on organization of physical education at school (Detynych, 2019; Tkachenko, 2020).

The study confirmed the possibility of using a discriminant function to assess the effectiveness of different modes of physical exercises when teaching acrobatic exercises, as the verification of canonical functions indicates their statistical significance.

\section{Conclusions}

Discriminant analysis made it possible to determine the impact of the number of repetitions on the effectiveness of developing the cartwheel skill in boys aged 15, answer the question as to how significantly the modes of repetition differ by the effectiveness of motor skills development, what class the object belongs to based on the values of discriminant variables.

Based on the analysis of group centroids, it was found that 6 repetitions of the exercise (6 sets 1 time each with a rest interval of $60 \mathrm{~s}$ ) significantly influence the cartwheel skill development in boys aged 15 during physical education classes. The results of group classification show that $95.0 \%$ of the original grouped observations were classified correctly.

\section{Acknowledgment}

The study was carried out according to the research plan of the Department of Theory and Methodology of Physical Education of H. S. Skovoroda Kharkiv National Pedagogical University within the topic "Theoretical and methodological foundations of modeling the learning process and motor abilities development in children and adolescents" (20132022) (state registration number 0112U002008).

\section{Conflict of interest}

The authors declare that there is no conflict of interest.

\section{References}

Krutsevich, T., Marchenko, O., Trachuk, S., Panhelova, N., Napadij, A., \& Dovgal, V. (2021). The Configuration of Educational Factors in the Family in Terms of their Impact on the Formation of Interest in Sports in Middle School Children. Teoriâ ta Metodika Fizičnogo Vihovannâ, 21(2), 101-106. https://doi.org/10.17309/tmfv.2021.2.01 
Cisterna, D., Forbes, C. T., \& Roy, R. (2019). Model-based teaching and learning about inheritance in third-grade science. International Journal of Science Education, 41(15), 2177-2199. https://doi.org/10.1080/09500693.2019.1663561

Elezi, A., Elezi, G., Gontarev, S., \& Georgiev, G. (2021). Secular trends in anthropometric characteristics and healthrelated physical fitness in macedonian children: The makfit studies. Teoria ta Metodika Fizicnogo Vihovanna, 21(1), 12-18. https://doi.org/10.17309/tmfv.2021.1.02

Ivashchenko, O. (2020). Research Program: Modeling of Motor Abilities Development and Teaching of Schoolchildren. Teoriâ ta Metodika Fizičnogo Vihovannâ, 20(1), 32-41. https://doi.org/10.17309/tmfv.2020.1.05

Kapkan, O. O., Khudolii, O. M., \& Bartík, P. (2019a). Motor skills development: Optimization of teaching boys aged 14. Teoria ta Metodika Fizicnogo Vihovanna, 19(3), 148155. Scopus. https://doi.org/10.17309/tmfv.2019.3.06

Kapkan, O. O., Khudolii, O. M., \& Bartík, P. (2019b). Pattern recognition: Motor skills development in girls aged 15 . Teoria ta Metodika Fizicnogo Vihovanna, 19(1), 44-52. Scopus. https://doi.org/10.17309/tmfv.2019.1.06

Herrmann, C., Heim, C., \& Seelig, H. (2019). Construct and correlates of basic motor competencies in primary schoolaged children. Journal of Sport and Health Science, 8(1), 63-70. Scopus. https://doi.org/10.1016/j.jshs.2017.04.002

Morley, D., Van Rossum, T., Richardson, D., \& Foweather, L. (2019). Expert recommendations for the design of a children's movement competence assessment tool for use by primary school teachers. European Physical Education Review, 25(2), 524-543. https://doi.org/10.1177/1356336X17751358

Samsudin, S., Setiawan, I., Taufik, M. S., \& Solahuddin, S. (2021). Volleyball Fundamental Movement Learning Model in Primary School. Teoriâ ta Metodika Fizičnogo Vihovannâ, 21(3), 194-199.

https://doi.org/10.17309/tmfv.2021.3.02

Burstein, R. P., Luzon, Y., \& Moran, D. S. (2021). Exercise intensity when adjusted for an individual's maximal aerobic power positively affects executive functions in young adults. Journal of Physical Education and Sport, 21(2), 783790. https://doi.org/10.7752/jpes.2021.02097

Ivashchenko, O., Iermakov, S., Khudolii, O., Cretu, M., \& Potop, V. (2017). Level of physical exercises' mastering in structure of 11-13 yrs age boys' motor fitness. Pedagogics, Psychology, Medical-Biological Problems of Physical Training and Sports, 21(5), 236-243. https://doi.org/10.15561/18189172.2017.0506

Ivashchenko, O.V., \& Kapkan, O.O. (2015). Simulation of process of 14-15 years old girls' training of light athletic and gymnastic exercises. Pedagogics, psychology, medicalbiological problems of physical training and sports, 19(8), 32-39. http://dx.doi.org/10.15561/18189172.2015.0805

Iermakov, S., Khudolii, O., \& Chupikhin, D. (2021). Discriminant Analysis: Impact of the Number of Repetitions on the Effectiveness of Teaching Boys Aged 7 Throwing a Small Ball. Journal of Learning Theory and Methodology, 2(2), 7581. https://doi.org/10.17309/jltm.2021.2.04

Ivashchenko, O., Nosko, M., Cieślicka, M., \& Malyshev, D. (2019). Motor Abilities: Peculiarities of Strength Effort Assessment in Boys Aged 11-13. Teoriâ ta Metodika Fizičnogo Vihovannâ, 19(1), 37-43. https://doi.org/10.17309/tmfv.2019.1.05

Ivashchenko, O., Khudolii, O., \& Jagiello, W. (2021). Strength abilities: Pattern recognition method in the management of the cumulative effect of strength loads in 8-year-old boys. Pedagogy of Physical Culture and Sports, 25(4), 253 260. https://doi.org/10.15561/26649837.2021.0407

Khudolii, O., Iermakov, S., Ivashchenko, O., \& Nosko, M. (2020). Strength Abilities: Modeling of Immediate and Delayed Training Effect of Strength Loads in Boys Aged 8 Years. Teoriâ ta Metodika Fizičnogo Vihovannâ, 20(4), 248 255. https://doi.org/10.17309/tmfv.2020.4.08

Khudolii, O., Iermakov, S., \& Bartik, P. (2020). Didactics: Methodological Basis of Motor Learning in Children and Adolescents. Journal of Learning Theory and Methodology, 1(1), 5-13. https://doi.org/10.17309/jltm.2020.1.01

Ivashchenko, O., Iermakov, S., \& Khudolii, O. (2021). Modeling: Ratio between means of teaching and motor training in junior school physical education classes. Pedagogy of Physical Culture and Sports, 25(3), 194-201. https://doi.org/10.15561/26649837.2021.0308

Iermakov, S., Ivashchenko, O., Khudolii, O., Chernenko, S., Veremeenko, V., \& Zelenskyi, B. (2021). Pattern Recognition: Impact of Exercises Modes on Developing a Small Ball Throwing Skill in Boys Aged 8. Teoriâ ta Metodika Fìzičnogo Vihovannâ, 21(1), 77-83. https://doi.org/10.17309/tmfv.2021.1.10

Iermakov, S., Khudolii, O., \& Chupikhin, D. (2021). Discriminant Analysis: Impact of the Number of Repetitions on the Effectiveness of Teaching Boys Aged 7 Throwing a Small Ball. Journal of Learning Theory and Methodology, 2(2), 7581. https://doi.org/10.17309/jltm.2021.2.04

Samanta, A., \& Mukherjee, S. (2021). Surface Electromyography Based Core Muscle Fatigue Analysis During Repetitive Plank Using Multivariate Dimensionality Reduction Methods in Boys Aged 12-14. Teoriâ ta Metodika Fizičnogo Vihovannâ, 21(3), 253-263. https://doi.org/10.17309/tmfv.2021.3.09

Marchenko, S., \& Handymov, B. (2021). Development of Strength Abilities Using Play Techniques with Elements of Martial Arts at the Sports and Recreational Stage in 10-Year-Old Girls. Journal of Learning Theory and Methodology, 2(2), 6874. https://doi.org/10.17309/jltm.2021.2.03

Detynych, S. O. (2019). Comparative overview of functional and motor preparedness of boys aged 13-14. Teoria ta Metodika Fizicnogo Vihovanna, 19(2), 89-97. Scopus. https://doi.org/10.17309/tmfv.2019.2.05

Tkachenko, M. (2020). Peculiarities of Motor Fitness Dynamics of 5TH-6TH Grade Students during a School Year. Teoria ta Metodika Fizicnogo Vihovanna, 20(1), 49-55. Scopus. https://doi.org/10.17309/tmfv.2020.1.07

Warlop, G., Vansteenkiste, P., Lenoir, M., \& Deconinck, F. J. A. (2020). An exploratory study of gaze behaviour in young adults with developmental coordination disorder. Human Movement Science, 73. https://doi.org/10.1016/j.humov.2020.102656

Strotmeyer, A., Kehne, M., \& Herrmann, C. (2020). Basic motor competencies: Correlations with sex, age, weight status, extracurricular sports activity and the performance of motor coordination. German Journal of Exercise and Sport Research, 50(1), 82-91. Scopus. https://doi.org/10.1007/s12662-019-00596-Z

Khudolii, O.M. (2008). Osnovy metodyky vykladannia himnastyky: Navch. posibnyk. U 2-kh tomakh. 4-e vyd., vypr. i dop. Kharkiv: «OVS», T. 1, 408.

Shlemin, A.M. (1973). Iunyi gimnast. M.: Fizkultura i sport, 376. 


\title{
РОЗПІЗНАННЯ ОБРАЗІВ: ЕФЕКТИВНІСТЬ ПРОЦЕСУ НАВЧАННЯ ПЕРЕВОРОТУ УБІК ХЛОПЦІВ 15 РОКІВ
}

\author{
Дмитро Іванов ${ }^{1 \mathrm{ABCD}}$, Ольга Іващенко ${ }^{1 \mathrm{ABCD}}$, Павол Бартік ${ }^{2 \mathrm{ACD}}$ \\ ${ }^{1}$ Харківський національний педагогічний університет імені Г.С. Сковороди \\ ${ }^{2}$ Університет Матея Беля \\ Авторський вклад: А - дизайн дослідження; В - збір даних; C - статаналіз; D - підготовка рукопису; Е - збір коштів \\ Реферат. Статья: 6 с., 9 табл., 2 рис., 28 джерел.
}

Мета дослідження - визначити вплив кількості повторень на ефективність процесу навчання перевороту убік хлопців 15 років.

Матеріали і методи. У дослідженні прийняли участь 20 хлопців 15 років. Діти та їхні батьки були інформовані про всі особливості дослідження і дали згоду на участь в експерименті. Для вирішення поставлених завдань були використані методи дослідження: вивчення та аналіз науково-методичної літератури; педагогічне спостереження, хронометраж навчальних завдань; педагогічний експеримент, методи математичної статистики, дискримінантний аналіз.

Результати. Приймається припущення про суттєвий вплив режимів чергування повторень вправ та інтервалу відпочинку на ефективність формування рухових навичок у хлопців 15 років. Встановлено що 6 підходів по 1 разу 3 інтервалом відпочинку 60 с має більшу ефективність ніж
6 підходів по 2 рази з інтервалом відпочинку 60 с у процесі навчання умінню оцінювати виконання рухів за часом ( $\mathrm{p}<$ 0,001). Менша кількість повторень при першому режимі виконання вправ необхідна і для оволодіння перевороту убік в цілому. Це пов'язано з тим, що для диференціювання часових характеристик необхідна термінова інформація про виконання руху після кожного повторення.

Висновки. На основі аналізу центроїдів груп визначено, що 6 повторень вправи (6 підходів по 1 разу з інтервалом відпочинку 60 с) має суттєвий вплив на процес формування навички виконання перевороту убік хлопців 15 років на уроках фізичної культури. Результати класифікації груп показують, що 95,0 \% вихідних згрупованих спостережень класифіковано вірно.

Ключові слова: дискримінантний аналіз, хлопці, акробатичні вправи, режим виконання вправ.

\section{Information about the authors:}

Ivanov Dmytro: dimonivanov2610@gmail.com; https://orcid.org/0000-0002-7547-9699; H. S. Skovoroda Kharkiv National Pedagogical University, Alchevskikh St, 29, Kharkiv, 61002, Ukraine.

Ivashchenko Olha: ivashchenko@hnpu.edu.ua; https://orcid.org/0000-0002-2708-5636; H. S. Skovoroda Kharkiv National Pedagogical University, Department of Theory and Methodology of Physical Education, Alchevskikh St, 29, Kharkiv, 61002, Ukraine.

Bartik Pavol: pavol.bartik@umb.sk; https://orcid.org/0000-0002-2087-7876; Matej Bel University, Department of Physical Education and Sports, Tajovského 40, 97401 Banská Bystrica, Slovakia.

Cite this article as: Ivanov, D., Ivashchenko, O., \& Bartik, P. (2021). Pattern Recognition: Effectiveness of Teaching Boys Aged 15 a Cartwheel. Journal of Learning Theory and Methodology, 2(3), 105-110. https://doi.org/10.17309/jltm.2021.3.01

Received: 25.09.2021. Accepted: 05.10.2021. Published: 30.10.2021

This work is licensed under a Creative Commons Attribution 4.0 International License (http://creativecommons.org/licenses/by/4.0). 